\title{
Phytochemicals screening and antimicrobial activities of selected medicinal plants of Khyberpakhtunkhwa Pakistan
}

\author{
Iqbal Hussain ${ }^{1 \star}$, Moneeb Ur Rehman Khattak ${ }^{1}, \operatorname{Riaz}_{\text {ullah }}^{1,3}$, Zia Muhammad ${ }^{1}$, Naeem Khan ${ }^{1}$, \\ Farhat Ali Khan ${ }^{2}$, Zahoor Ullah ${ }^{3}$ and Sajjad Haider ${ }^{3}$
${ }^{1}$ Department of Chemistry, Kohat University of Science and Technology Kohat-26000, Pakistan.
${ }^{2}$ Department of Pharmacy Sarhad University of Science and Information Technology Peshawar-25000, Pakistan.
${ }^{3}$ Department of Chemical Engineering, College of Engineering, King Saud University, P. O. BOX 800, \\ Riyadh 11421, Saudi Aarbia.
}

Accepted 24 May, 2011

\begin{abstract}
The study was carried out to assess the phytochemical and antimicrobial bioassay of five medicinal plants, Lepidium sativum, Nerium oleander, Ranunculus repens, Tecoma stans and Urtica dioca. These plants are traditionally used as medicine in the Northwest Pakistan, therefore it is necessary to identify and estimate their alkaloid, flavonoid, saponin, phenol and tannin contents. Phytochemical inveigation of plant samples determines that alkaloid $(63.6 \%)$ and flavonoid $(0.91 \%)$ were highest in $N$. oleander, saponin $(11 \%)$ and phenol $(0.031)$ in $T$. stans, tannin $(0.61 \%)$ in $L$. sativum, All five species showed no significant antimicrobial activities.
\end{abstract}

Key words: Medicinal plants, phytochemical analysis, antimicrobial activities

\section{INTRODUCTION}

The world is fertile with natural and medicinal plants. Medicinal plants are now more focused than ever because they have the capability of producing many benefits to society indeed to mankind, especially in the line of medicine and pharmacological. The medicinal power of these plants lies in phytochemical constituents that cause definite pharmacological actions on the human body (Akinmoladun et al., 2007). Phytochemical, natural compound occur in plants such as medicinal plants, vegetables and fruits that work with nutrients and fibers to act against diseases or more specifically to protect against diseases.

The phytochemicals are grouped into two main categories (Krishnaiah et al., 2009) namely primary constituents which includes amino acids, common sugars, proteins and chlorophyll etc., and secondary constituents consisting of alkaloids, essential oils, flavonoids, tannins, terpenoids, saponins, phenolic compounds etc. (Krishnaiah et al., 2007; Edeoga et al., 2005). Majority of phytochemicals have been known to bear valuable

Corresponding author. E-mail: naseemyar@yahoo.com. therapeutic activities such as insecticidals (Kambu et al., 1982), antibacterial, antifungal (Lemos et al., 1990), anticonstipative (Ferdous et al., 1992), spasmolytic (Sontos et al., 1998), antiplasmodial (Benoitvical et al., 2001) and antioxidant (Vardar-unlu et al., 2003) activities etc. The plants thus find their medicinal value due to respective phytochmical constituents they contains.

Infectious diseases are the leading causes of death through out the world that accounts for nearly one half of all death in the tropical countries, which are also becoming a serious problem in developed countries. It is calculated that infectious diseases are the main causes of death in $8 \%$ of the 9 deaths occurring in United States (Demissew and Dagne, 2001). In addition, antibiotics are sometime associated with adverse effects including hypersensitivity, immuno suppressant and allergic reactions. Given the alarming incidence of antibiotic resistance in bacteria of medical importance, there is a constant need for new and effective therapeutic agents. Therefore, there is a need to develop alternative antimicrobial drugs for the treatment of infectious diseases from medicinal plants. Lepidium sativum, Nerium oleander, Ranunculus repens, Tecoma stans and Urtica dioca are medicinally very important plants and 
use extensively in pharmaceutical formulations and are also use by local practitioners for a variety of human diseases. Hence the aim of this study was to determine the phytochemical constituents and to investigate the antimicrobial properties so as to ascertain their uses in traditional medicines.

\section{MATERIAL AND METHODS}

\section{Preparation of sample}

The aqueous extract of each sample was prepared by soaking $10 \mathrm{~g}$ of powdered samples in $200 \mathrm{ml}$ of distilled water for $12 \mathrm{~h}$. The extract was filtered through Watt man filter paper. The phytochemicals in each sample was determined qualitatively and quantitatively (Krishnaiah et al., 2009; Mattila et al., 2007).

\section{Qualitative analysis of phytochemicals}

\section{Alkaloids}

The extracts were evaporated to dryness and the residues were heated with $2 \%$ Hydrochloric acid on a boiling water bath. The extract were cooled, filtered and treated with the Mayer's reagent. The sample was then observed for the presence of yellow precipitation or turbidity (Tyler and Herbalgram, 1994, Harborne et al., 1973).

\section{Flavonoids}

$1.5 \mathrm{ml}$ of $50 \%$ methanol was added to $4 \mathrm{ml}$ of extracts. Warmed the solution and metal magnesium was added. Then added 5 to 6 drops of concentrated hydrochloric acid to the solution and observed for red coloration (Tyler and Herbalgram, 1994; Harborne et al., 1973).

\section{Tannins}

To $0.5 \mathrm{ml}$ of extract solution, $1 \mathrm{ml}$ of distilled water and 1 to 2 drops of Ferric chloride solution was added, observed for blue or green black coloration (Tyler and Herbalgram 1994; Harborne et al., 1973).

\section{Phenol}

$2 \mathrm{ml}$ ethanol was added to the test solution and few drops of ferric chloride solution and observed for coloration (Tyler and Herbalgram, 1994; Harborne et al., 1973).

\section{Saponins}

$2 \mathrm{ml}$ of distilled water was added to $2 \mathrm{ml}$ of the test solution and shaked well and observed for frothing (Tyler and Herbalgram, 1994; Harborne et al., 1973)

\section{Quantitative analysis}

Alkaloids

$5 \mathrm{~g}$ of the plant sample was prepared in a beaker and $200 \mathrm{ml}$ of $10 \%$ $\mathrm{CH}_{3} \mathrm{CO}_{2} \mathrm{H}$ in $\mathrm{C}_{2} \mathrm{H}_{5} \mathrm{OH}$ is added to the plant sample. The mixture is covered and allowed to stand for $4 \mathrm{~h}$. The mixture was then filtered and the extract is allowed to become concentrated in a water bath until it reaches $1 / 4$ of the original volume. Concentrated ammonium hydroxide was added until the precipitation is complete. The whole solution is allowed to settle and the precipitate is collected and washed with dilute ammonium hydroxide and then filtered. The residue is alkaloid, which is then dried and weighed.

\section{Flavonoids}

Extracted $10 \mathrm{~g}$ of the plant sample with $100 \mathrm{ml}$ of $80 \%$ aqueous methanol at room temperature. The whole solution was filtered and the filtrate was then transferred into a water bath. The solution was evaporated to dryness and weighed to a constant weight (Williamson and Manach, 2005; Mattila and Hellström, 2007).

\section{Saponins}

$20 \mathrm{~g}$ of each ground plant samples were put into a conical flask and $100 \mathrm{ml}$ of $20 \%$ ethanol was added to the plant sample. The said sample is heated over a water bath for $4 \mathrm{~h}$ at about $55^{\circ} \mathrm{C}$ with continuous stirring. The extracted mixture is then filtered and the residue is then re-extracted again with $200 \mathrm{ml}$ of $20 \%$ ethanol. The collective residues are reduced to $40 \mathrm{ml}$ over a hot water bath. The concentrated is then transferred to a separating funnel and $20 \mathrm{ml}$ of diethyl ether is added to the plant extract and the shaken vigorously. The aqueous layer was recovered while the organic layer was discarded and the process of purification was repeated. Sixty milliliter of $\mathrm{n}$ - Butanol was added and combined $\mathrm{n}$ - Butanol extract were washed twice with $10 \mathrm{ml}$ of $5 \%$ sodium chloride. The remaining solution was then heated on water bath and after evaporation; the samples were dried in oven to a constant weight.

\section{Tannins}

$500 \mathrm{mg}$ of plant sample was weighed and transferred to $50 \mathrm{ml}$ flask. Then added $50 \mathrm{ml}$ of distilled water and stirred for $1 \mathrm{~h}$. Sample was filtered into a $50 \mathrm{ml}$ volumetric flask and the volume was made up to the mark. $5 \mathrm{ml}$ of the filtered sample was pipette into test tube and then mixed with $2 \mathrm{ml}$ of $0.1 \mathrm{M}$ ferric chloride. The absorbance was measured using spectrophotometer at $395 \mathrm{~nm}$ wavelength within 10 min (Tyler and Herbalgram, 1994; Harborne et al., 1973).

\section{Phenols}

Plants sample was boiled for $15 \mathrm{~min}$ with $50 \mathrm{ml}$ of $\left(\mathrm{CH}_{3} \mathrm{CH}_{2}\right)_{2} \mathrm{O} .5 \mathrm{ml}$ of the sample was pipette into $50 \mathrm{ml}$ flask, and $10 \mathrm{ml}$ of distilled water was added. Then $2 \mathrm{ml}$ of $\mathrm{NH}_{4} \mathrm{OH}$ solution and $5 \mathrm{ml}$ of concentrated $\mathrm{CH}_{3}\left(\mathrm{CH}_{2}\right)_{3} \mathrm{CH}_{2} \mathrm{OH}$ was added to the mixture. The sample was made up to the mark and left to react for 30 min for color development and measured for $505 \mathrm{~nm}$ wave length using a spectrophotometer (Tyler and Herbalgram 1994; Harborne et al., 1973).

\section{Antimicrobial activity \\ Preparation of crude extract}

$100 \mathrm{~g}$ of each of the coarsely powdered plant material was taken and extracted with ethanol, water and $n$-hexane. The extracts was filtered and sodium chloride solution was then added to the filtered extract to form precipitates. The precipitates were then separated, air dried and transferred to air tight amber glass container. The 
Table 1. Qualitative analysis of phytochemicals.

\begin{tabular}{lccccc}
\hline Sample code & Alkaloid & Flavonoid & Saponin & Tannin & Phenol \\
\hline L. sativum & $+\mathrm{ve}$ & $+\mathrm{ve}$ & $+\mathrm{ve}$ & $+\mathrm{ve}$ & $+\mathrm{ve}$ \\
N. oleander & $+\mathrm{ve}$ & $+\mathrm{ve}$ & $+\mathrm{ve}$ & $+\mathrm{ve}$ & $+\mathrm{ve}$ \\
R. repens & $+\mathrm{ve}$ & $+\mathrm{ve}$ & $+\mathrm{ve}$ & $+\mathrm{ve}$ & $+\mathrm{ve}$ \\
T. stans & $+\mathrm{ve}$ & $+\mathrm{ve}$ & $+\mathrm{ve}$ & $+\mathrm{ve}$ & $+\mathrm{ve}$ \\
U. dioca & $+\mathrm{ve}$ & $+\mathrm{ve}$ & $+\mathrm{ve}$ & $+\mathrm{ve}$ & $+\mathrm{ve}$ \\
\hline
\end{tabular}

Table 2. Quantitative analysis of phytochemicals.

\begin{tabular}{lccccc}
\hline Sample code & Alkaloid (\%) & Flavonoid (\%) & Saponin (\%) & Tannin(\%) & Phenol (\%) \\
\hline L. sativum & 0.40 & 0.42 & 2.8 & 0.61 & 0.004 \\
N. oleander & 63.6 & 0.91 & 9 & 0.01 & 0.003 \\
R. repens & 0.80 & 0.39 & 5 & 0.01 & 0.004 \\
T. stans & 51.5 & 0.53 & 11 & 0.19 & 0.031 \\
U. dioca & 12.8 & 0.60 & 3.1 & 0.21 & 0.006 \\
\hline
\end{tabular}

crude extract was dissolved in chloroform and water to make the final concentration, which was kept in refrigerator till use (Harborne et al., 1973).

\section{Preparation of standard bacterial suspension}

The average number of viable, Bacillus subtilis (NCTC8236), Escherichia coli (ATCC25922), Proteus vulgaris (ATCC6380), Pseudomonas aeruginosa (ATCC27853), Salmonella typhimurium (ATCC0650) and Staphylococcus aureus (NCTC25953) organism per milliter of the stock suspension was determined by means of the surface viable counting technique. About $\left(10^{8}\right.$ to $\left.10^{9}\right)$ colony forming units per milliters was used. A fresh stock suspension was prepared each time (Lang et al., 1990; Bylka et al., 2004).

\section{Test for antibacterial activity}

The antimicrobial activity of the prepared extracts was determined by using well agar diffusion method. The standardized bacterial stock suspension $\left(10^{8}\right.$ to $\left.10^{9}\right)$ colony forming units per milliter was mixed with $60 \mathrm{ml}$ of sterile nutrient agar thoroughly. $20 \mathrm{ml}$ inoculated nutrient agar was poured into sterile Petri dishes. The agar was left to set and four well $10 \mathrm{~mm}$ in diameter was made in each of these plates using sterile cork borer No 8 and then agar discs were removed. The entire well was filled with $0.1 \mathrm{ml}$ of each extracts using microtiter-pipette and allowed to diffuse at room temperature for $2 \mathrm{~h}$. The plates were incubated at $37^{\circ} \mathrm{C}$ for $24 \mathrm{~h}$. Two replicates were also performed for each extract against each of the test organism. Simultaneously addition of the respective solvent instead of extract was carried out as controls. After incubation, the zones of inhibition were measured and mean value was calculated (Hanna et al., 2008; Roberts and Wink, 1998).

\section{Preparation of standard fungal suspension}

The fungal cultures, Aspergillus niger (ATCC 9763) and Candida albicans (ATCC7596) were maintained on saboraud dextrose agar, incubated at $25^{\circ} \mathrm{C}$ for four days. The fungal growth was harvested and washed with sterile normal saline and the suspension was stored in refrigerator till used (Hanna et al., 2008; Roberts and Wink, 1998).

\section{Test for anti fungal activity}

The method applied for determination of antifungal activity is the same as for antibacterial activity. The media used is sterile yeast and mould extract agar. C. albican is incubated for two days while A. niger for three days at $25^{\circ} \mathrm{C}$.

\section{RESULTS AND DISCUSSION}

Phytochemicals are plant-derived chemical compounds which are non-essential nutrients, some of which show potential health-promoting properties.

\section{Qualitative analysis}

As can be seen from Table 1, alkaloids, flavonoids, saponins, tannins and phenols were present in studied plant samples.

\section{Quantitative analysis}

\section{Alkaloids}

As can be seen from Table 2, high concentration $63.6 \%$ of alkaloids was found in $N$. oleander and less concentration of $0.40 \%$ was noted in $L$. sativum .The concentration of alkaloids in the rest of samples are as follow: $51.5 \%$ in $T$. stans, $0.80 \%$ in $R$. repens and $12.8 \%$ 
Table 3. Zones of inhibitions of water extracts of selected medicinal plants.

\begin{tabular}{lcccccccc}
\hline Water extract of the plant & $\mathbf{1}$ & $\mathbf{2}$ & $\mathbf{3}$ & $\mathbf{4}$ & $\mathbf{5}$ & $\mathbf{6}$ & $\mathbf{7}$ & $\mathbf{8}$ \\
\hline L. sativum & 11 & 13 & 8 & 2 & 4 & 1 & 3 & 2 \\
N. oleander & 14 & 9 & 12 & 6 & 3 & 2 & 0 & 1 \\
R. repens & 12 & 10 & 7 & 5 & 2 & 4 & 2 & 1 \\
T. stans & 10 & 8 & 12 & 4 & 2 & 6 & 2 & 2 \\
U. dioca. & 15 & 11 & 13 & 6 & 2 & 0 & 3 & 1 \\
\hline
\end{tabular}

Zones of inhibitions in millimeter: Gram positive bacteria: 1 , B. subtillis; 2, P. vulgaris, 3, S. aureus, Gram negative bacteria: 4, E. coli; 5 , P. aeruginosa; 6, S.typhi. Fungi: 7, A.niger; 8, C.albicans.

in $U$. dioca. The use of alkaloid contains plants as dyes, spices, drugs or poisons can be traced back almost to the beginning of civilization (Roberts and Wink, 1998). They are well known for their CNS activities (Lewis and Elvin, 2003).

\section{Flavonoids}

Flavonoids are plant nutrients that when consumed in the form of fruits and vegetables are non-toxic as well as potentially beneficial to the human body; up till now, more than 2000 different flavonoids have been isolated from vegetables (Taiz and Ziegler, 2006). High percentage of flavonoids $(0.91 \%)$ was determined in $N$. oleander followed by $0.60 \%$ in U. dioca, $0.53 \%$ in $T$. stans, $0.42 \%$ in L. sativum and $0.39 \%$ in $R$. repens.

\section{Saponins}

Pharmacological activities have been reported about saponins such as antibiotic, antifungal, antiviral, hepatoprotective anti-inflammatory and anti-ulcer (Oakenfull, 1986; Zhang, 2001). Table 2 shows that the percentage of saponins (11\%) was found very in $T$. stans, followed by $9 \%$ in $N$. oleander and $5 \%$ in $R$. repens. U. dioca contains $3.1 \%$ of saponins while in $L$. sativum the percentage was obtained in low concentration $2.8 \%$.

\section{Tanins}

The concentration $0.61 \%$ was detected in $L$. sativum followed by $0.21 \%$ in $U$. dioca, $0.19 \%$ in $T$. stans while in the rest of samples, concentration of tannins was recoded $0.01 \%$. Tannins are basically use for the treatment of inflammation, leucorrhoea, gonorrhea, burn, piles, diarrhea and as antidote in the treatment of alcaloidal poisoning (Buzzini et al., 2008). They are also used for tannin of animal hides to convert them to leather.

\section{Phenols}

Phenols are very wide spread in nature. They range from simple structures having a simple aromatic ring to highly complex polymeric structures and often exist in glycosidic forms (Williamson and Manach, 2005). Capsacin is found in the dried ripe fruit of different species of Capsicum. It had been used internally for dyspepsia and flatulence. Externally, it is frequently used as counterirritant (Mattila and Hellström, 2007). Table 2 shows very low concentration of phenols in the whole plant samples which range from 0.004 to $0.19 \%$.

\section{Antimicrobial assay}

Sustainable amount of new antibiotic available in the market are obtained from natural or semi synthetic resources are obtained from about $20 \%$ of the plants present in world which were submitted to pharmaceutical or biological test. As can be seen from the analytical results obtained from the zone of inhibition of water extracts (Table 3 ) of five selected medicinal herbs

\section{Water extract}

Table 3 shows high activity $15 \mathrm{~mm}$ recorded from the crude extract of $U$. dioca against $B$. subtillis while less activity. $10 \mathrm{~mm}$ was obtained from the crude extract of $T$. stans against $B$. subtillrespectivelyis. The high activity of $L$. sativum extract against $P$. vulgaris is $13 \mathrm{~mm}$ while 11 $\mathrm{mm}$ was recorded against the same bacteria in $U$. dioca of water extract. $R$. repens has showed $10 \mathrm{~mm}$ activity against $P$. valgaris. The activities of the other water extracts were relatively small; 9 and $8 \mathrm{~mm}$ was found in $N$. oleander and $T$. stans extracts. T. stans and $N$. oleander showed equal activity of $12 \mathrm{~mm}$ against $S$. aureus while less activity of $7 \mathrm{~mm}$ was recorded in $R$. repens. An equal activity of $6 \mathrm{~mm}$ was observed in $N$. oleander and $U$. dioca against $E$. coli followed by 5,4 and $2 \mathrm{~mm}$ in $R$. repens, $T$. stans and L. sativum, respectively against the pathogen $E$. coli. High activity of $4 \mathrm{~mm}$ was shown by $L$. sativum against $P$. aeruginosa while $3 \mathrm{~mm}$ activity recorded in $N$. oleander against same bacteria and same relatively low activiat $6 \mathrm{~mm}$ against $S$. typhi while $4 \mathrm{~mm}$ activity was observed from $R$. repens. Low activity of 2 and $1 \mathrm{~mm}$ was shown by $N$. oleander and $L$. 
Table 4. Zones of inhibitions of chloroform extracts of selected medicinal plants.

\begin{tabular}{lcccccccc}
\hline Chloroform extract of the plant & $\mathbf{1}$ & $\mathbf{2}$ & $\mathbf{3}$ & $\mathbf{4}$ & $\mathbf{5}$ & $\mathbf{6}$ & $\mathbf{7}$ & $\mathbf{8}$ \\
\hline L. sativum & 9 & 16 & 11 & 2 & 4 & 7 & 2 & 1 \\
N. Oleander & 11 & 7 & 12 & 5 & 4 & 2 & 2 & 2 \\
R. repens & 13 & 10 & 15 & 3 & 0 & 5 & 1 & 0 \\
T. Stans & 15 & 7 & 14 & 7 & 3 & 0 & 2 & 4 \\
U. Dioca. & 17 & 11 & 9 & 5 & 3 & 1 & 2 & 1 \\
\hline
\end{tabular}

Zones of inhibitions in millimeter: Gram positive bacteria: 1 , B. subtillis; 2, P. vulgaris, 3, S. aureus, Gram negative bacteria: 4, E. coli; 5 , P. aeruginosa; 6, S.typhi. Fungi: 7, A.niger; 8, C.albicans.

sativum while $U$. dioca showed no activity. $L$. sativum and $U$. dioca showed high activity of $3 \mathrm{~mm}$ against $A$. niger while $2 \mathrm{~mm}$ activity was found from $R$. repens and $T$. stans extracts while $N$. oleander showed no activity against $A$. niger. High activity of $2 \mathrm{~mm}$ was noted in both $L$. sativum and $T$. stans against $C$. albicans whilet same 1 $\mathrm{mm}$ activity was recorded in the rest of the plant extracts.

\section{Chloroform extract}

Table 4 shows high activity of $17 \mathrm{~mm}$ determined in the crude extract of $U$. dioca from chloroform extract against $B$. subtillis while the activity shown by the rest of the plant extracts were in between 9 to $15 \mathrm{~mm}$. Activity of $16 \mathrm{~mm}$ was recorded in the extract of $L$. sativum against $P$. vulgaris and 11, 10, 7 and $7 \mathrm{~mm}$ activities were found in $U$. dioca, $R$. repens, $N$. oleander and $T$. stans, respectively. $R$. repens extract showed $15 \mathrm{~mm}$ activity against $S$. aureus while less activity was found $9 \mathrm{~mm}$ in extract of $L$. sativum. Activity of $7 \mathrm{~mm}$ was recorded in $T$. stans extract against $E$. coli. $5 \mathrm{~mm}$ activity was recorded in both crude extracts of $N$. oleander and $U$. dioca. While 3 and 2 $\mathrm{mm}$ activities were also observed. Extracts of $N$. oleander and $L$. sativum were more active, $4 \mathrm{~mm}$ against $P$. aeruginosa while $T$. stans and $U$. dioca also showed same activity, $3 \mathrm{~mm}$ and no activity was seen of $R$. repens against same organism. Activity of $7 \mathrm{~mm}$ was shown by $L$. sativum against $S$. typhi, $5 \mathrm{~mm}$ by $R$. repens, $2 \mathrm{~mm}$ by $N$. oleonder, $1 \mathrm{~mm}$ by $U$. dioca and no activity by $T$. stans against $S$. typhi.

Same antifungal activity of $2 \mathrm{~mm}$ was determined against $A$. niger by most of the plants except $R$. repens which was $1 \mathrm{~mm}$. $T$. stans was noted more active at 4 $\mathrm{mm}$ against $C$. albicans followed by 2,1 and $1 \mathrm{~mm}$ in $N$. oleander, $L$. sativum and $T$. stans respectively while no activity was shown by $R$. repens.

\section{REFERENCES}

Akinmoladun AC, Ibukun EO, Afor E, Obuotor EM, Farombi EO (2007). Pytochemical constituents and antioxidant activity of extract from the leaves of the Ocimum graticcimum. Sci. Res. Essay, 2: 163-166.

Benoitvical F, Valentin A, Mallic M, bassierc JM (2001). Antiplasmodial activity of Colchlospermum planchonii and $C$. tinctorium tubercle essential oils. J. Essent. Oil Res., 13: 65-67.

Buzzini P, Arapitsas P, Goretti M, Brand E, Turchetti B, Pinelli P, Leri F,
Romani A (2008). Antimicrobial and antiviral activity of hydrolysable tannins Mini. Rev. Med. Chem., 8: 1179-1178.

Bylka W, Szaufer M, Matalwaska I (2004). Antimicrobial activity of isocytisoside and of Aquilegia valgaris L. Lett. Appl. Micro., 39: 93-97.

Demissew S, Dagne E (2001). Basic and Applied Research on Medicinal Plants of Ethiopia, In: Proceedings of National Workshop on Conservation and Sustainable Use of Medicinal Plants in Ethiopia, Addis Ababa, p. 29.

Edeoga HO, Okwu D, Mbaebie BO (2005). Phytochemical constituents of some Nigerian Medicinal plants. Afri. J. Biotechnol., 4(7): 685-688.

Ferdous AJ, islam SM, Ahsan M.hassan.CM, Ahmad ZV (1992). In vitro antibacterial activity of the volatile oil of Nigella sativa seeds against multiple drug-resistant isolates of Shigella spp. and isolates of Vibrio cholerae and Escherichia coli: Phytother. Res., 6: 137-140,

Hanna K (2008). Examination of antibacterial and antifungal activity of selected non-antibiotic products. Acta. Pol. Drug Res., 65: 779-782.

Harborne JB (1973). Phytochemical methods, London Chapman and Hall, Ltd, pp. 49-88.

Kambu K, Di Phenzu, N Coune C, Wauter JN, Angenot L (1982). Plants Medicine ET Phytotherapie, p. 34.

Krishnaiah D, Devi T, Bono A, Sarbatly R (2009). Studies on phytochemical constituents of six Malaysian medicinal plants. J. Med. Plants Res., 3(2): 67-72.

Krishnaiah D, Sarbatly R, Bono A (2007). Phytochemical antioxidants for health and medicine - A move towards nature. Biotechnol. Mol. Biol, Rev., 1(4): 097-104.

Lang I, Nekam K, Gonzalez-Cabello R (1990). Hepatoprotective and immunological effects of antioxidant drugs. Tokai J. Exp. Clin. Med., 15: 123-127.

Lemos TLG, Matos FJA, Alencar JW, Crareiro AA, Clark AM, Chesnary JD (1990). Antimicrobial activity of essential oils of Brazilian plants: Phytopther. Res., 4: 82-84.

Lewis WH, Elvin-Lweis PF (2003). Medical botany: Plants affecting human health. 2 editions John Wiley \& Sons, Washington.

Mattila P, Hellström J (2007). Phenolic acids in potatoes, vegetables, and some of their products. J. Food Compos Anal., 20: 152-60.

Oakenfull DG (1986). Aggregation of bile acids and saponins in aqueous solution, Austr. J. Chem., 39 1671-1683.

Roberts MF, Wink M (1998). Alkaloids: Biochemistry. Ecology and Medicinal Applications. Plenum Press, Wew York.

Sontos FA, Rao VSN, silveria ER (1998). Investigations on the antinociceptive effect of Psidium guajava leaf essential oil and its major constituents. Phytother. Res., 12: 24-27.

Taiz L, Ziegler E (2006). Plant Physiology, $4^{\text {th }}$ edn, ch. 13.pp.315-344. Sinauer Associates, Publishers, Massamchusetts.

Tyler V (1994). Phytomedicines in Western Europe: their potential impact on herbal medicine in the United States Herbalgram; 30: 24-30.

Vardar-unlu G, Cadan F, Sokmen A (2003). Deferera, Polissiou, M. Sokmen, M. Donmez, E and tap bektas J. Agric. Food. Chem., pp. 51-63.

Williamson G, Manach C (2005). Bioavailability and bioefficacy of polyphenols in humans. II. Review of 93 intervention studies. Am. J. Clin. Nutr., 81(Suppl 1): S 243-55.

Zhang YW, Due DQ, Zhang L, Chen YJ, Yao XS (2001) Effects of Ginsenosides from Panax ginseng on cell-to-cell communication function mediated by gap junctions, Plants Med., 67: 417-422. 